\title{
The Effect of Ethno Science-Based Direct Instruction Learning Model in Physics Learning on Students' Critical Thinking Skill
}

\author{
Eko Risdianto*, Meli Junia Dinissjah, Nirwana, Muhammad Kristiawan \\ Universitas Bengkulu, Indonesia
}

Received December 7, 2019; Revised January 8, 2020; Accepted January 16, 2020

Copyright $\bigcirc 2020$ by authors, all rights reserved. Authors agree that this article remains permanently open access under the terms of the Creative Commons Attribution License 4.0 International License

\begin{abstract}
This paper aimed at discovering the effect of critical thinking skills after the Ethno science-based Direct Instruction learning model was implemented in physics learning. It was conducted in High School 3 of Bengkulu City. This paper used the Quasi Experiment. The sample was gained using sampling purposive technique that was XI Natural Science 2 as experiment class and XI Natural Science 4 as control class. The results obtained indicated that the post-test average score of critical thinking skills acquired in the class using the Ethno science-based Direct Instruction learning model and the class using a conventional learning model. Based on the data analysis result using a t-test, it showed that the Ethno science-based Direct Instruction learning model influenced the students' critical thinking skills. The post-test average score of experiment class using the Ethno science-based Direct Instruction learning model and the post-test score of control class using the conventional model showed that there was a significant difference. Based on the hypothesis test, it was found that the alternative hypothesis (Ha) could significantly be accepted. This paper concluded that the students' critical skill raised effectively when using Ethno science-based Direct Instructional Learning Model especially for Physics Learning and the paper suggests not to use conventional model.
\end{abstract}

Keywords Ethno Science, Direct Instruction Model, Critical Thinking Skill, Intensity and Intensity Level

\section{Introduction}

Recently, science and technology are significantly developed. Human in the current era is encountered with the industry revolution 4.0 that is Cyber-Physical Era [20]. The development of education in the world cannot be separated from the development of the industrial revolution, because indirectly, the change of economic development influences the education system in all countries [19]. It means that the education development is also affected by the culture owned by the countries. Human beings and culture cannot be separated, each of which forms the life. Human beings organize themselves become the socio-cultural unity, community. The human community builds, creates, grows, and develops culture: there is not humans without culture, and there is no culture without humans: there is no community without culture, and there is no culture without community [11]. The development of science is purposed for the students can implement the science that they have acquired in the school into real life in society; moreover, students can comprehend the phenomena, culture, and myth to be described scientifically. Learning in the school should also teach students on the sciences existed in the cultural phenomena developed in society [6].

In the Government Regulation Number 19 of 2005 about Education National Standard Article 14 verse (1), it is stated that Curriculum of secondary school or other similar educational institutions can insert the learning materials based on the local culture. It means that the government supports the effort in preserving culture. This effort can be conducted by inserting the learning program based on the local culture. The government regulation is developed in Curriculum 2013 that supports learning utilizes culture where should respond to the development of science, culture, technology, and arts that can create students' curiosity and skills utilizing it properly [5].

One way that can be implemented to develop the quality of the learning process is by using the aspect of local culture in the learning [4]. Ethno science is an activity in transforming the pure science of community and scientific science. Pure science consists of all science related to the fact of the community [17]. Pure science of the community is reflected through the local culture as a belief on nature and culture existing in society [16]. Generally, science learning at school 
is still centralized only in the materials provided in the handbook. It is still rare that there is science learning that reveals cultural fact in the real life of students [22] [24]. The content of the materials has not even been integrated with the culture. Therefore, it is needed to have the development of the learning method, one of which is by using the used approach. Implementing science learning using the Ethno science approach needs teachers' skills in integrating pure science and scientific science [16]. A strategy is successfully implemented it is supported by culture, and the true strategy is when it is related to the supporting culture [14] [15].

A learning model of Direct Instruction is applied when the teachers introduce the new learning topic and highlight the learning by defining the key concepts and show the relationships among the concepts [1] [12]. According to [4], the research finding shows that the implementation of Learning model of Ethno science-based Chemistry can improve the cognitive skill and critical thinking because the learning model connects the classroom learning with the phenomena encountered by students in their daily life, and also motivate students to actively participate in the learning process. In the research conducted by [5], it is found that local culture in the learning can improve the students' critical thinking skill. The students will learn effectively using the environment or things around them, thus, it stimulates the students' curiosity, to do an observation, to ask, to conclude, and to have the scientific experience. Response based on Indonesian Language Dictionary, is defined as a reaction, idea, and answer. Specifically, response based on a psychology dictionary is a muscle process occurring due to the stimulation in the form of answer or behavior. The answer may occur as a result of the test or questionnaire. Behavior can be in a form of change that exists in the individual either visible or invisible. Hence, in the learning process, response between teachers and students is significantly needed [21] [12] [13] [9] [7] [3] [23]. Based on the previous study, the Ethno science-Based Direct Instruction Model can improve critical thinking on the physics learning seen from N-gain's score which is in the high category [6]. In this study, the researchers will observe further the learning model of Ethno science-based direct instruction in physics learning toward the critical thinking of students.

\section{Research Methods}

The research that will be conducted is a quasi-experimental design in which there is no group taken randomly. The research uses a non-equivalent control group design in which the experiment group and control group are not chosen randomly (Sugiyono, 2018). The population in this research is all classes of XI Natural Science at State High School 3 of Bengkulu City. The sampling technique is a technique in choosing the sample. Sampling in this research is conducted based on purposive sampling. According to [2]
[18] [10] [21], purposive sampling is a technique in choosing the sample with certain consideration. Purposive sampling will produce a good result if it is conducted by the experts who understand the population and the location of unique problems. In this research, the one who has the consideration is the teacher of physics course for grade XI in the school. The teacher considers the classes that will be examined based on the daily test result of students which then examined using normality test, homogeneity test, and difference test. After finding the classes which are normal, homogenous, and there is no difference, thus the classes can be a sample. The sample used in this research is class XI Natural Science 2 as the experiment group and class XI Natural Science 4 as the control group. The research instrument consists of a lesson plan for the control class and the experiment.

\section{Results and Discussion}

This research is conducted in two classes as the research sample that is class XI Natural Science 4 as the experiment class and X Natural Science 2 as the control class. In the experiment class, it was implemented the treatment using the learning model of Ethno science-based Direct Instruction. Direct Instruction model was implemented through the steps comprising of 1) orientation, 2) Demonstration, 3) Guided Exercises, 4) Checking the understanding and giving feedback, and 5) giving individual exercises. Meanwhile, in the control class, it is provided a learning treatment that is usually implemented by teachers at High School 3 of Bengkulu City that is using lecturing method consisting of 1) teachers provide a good learning atmosphere before the lesson starts, 2) teachers explain the topic of the lesson, 3) teachers provide opportunities to the students to have a quiz, 4) teachers ask the students to conclude the learning result, and 5) teachers conduct the assessment on the students' understanding toward the lesson that has been explained [7] [8].

The test result of the critical thinking skill before giving the pre-test treatment and after giving the post-test treatment on the experiment class that is implemented Ethno science-based Direct Instruction Learning Model was conducted only in one meeting. It can be seen in the appendix of the experiment class test result. The table of pre-test, post-test, average and standard deviation score of experiment class can be in Table 1 .

Table 1. Test Result of Critical Thinking Skill in Experiment Class

\begin{tabular}{|c|c|c|}
\hline Test Result of Critical Thinking Skill & Mean & SD \\
\hline Pre-test & 16.19 & 8.43 \\
\hline Post-test & 82.38 & 14.25 \\
\hline
\end{tabular}

Based on the data of the Pre-test result, the result of critical thinking skill in the experiment class is 32.14 as the highest score, 3.57 as the lowest score and 16.19 as the pre-test 
average score with the standard deviation of 8.43. Based on the data of critical thinking skill test results of students who have joined the learning process, the post-test result was found. From the post-test result, there will be the average score, the highest score, the lowest score, and the standard deviation. Based on the test result of critical thinking skills in the experiment class, the highest score is 100 , the lowest score is 57.14 and the post-test average is 82.38 with the standard deviation of 14.25 .

The test result of critical thinking skill is the learning outcome that is used as a comparison in the experiment class. The test result of critical thinking skill before given the treatment of pre-test on the control class who involve the learning activity using the conventional way that is using lecturing method was also conducted once. The table of pre-test, post-test and standard deviation of the control class is provided in table 2 below.

Table 2. Test Result of Critical Thinking Skill in Control Class

\begin{tabular}{|c|c|c|}
\hline Test Result of Critical Thinking Skill & Mean & SD \\
\hline Pre-test & 13.87 & 6.91 \\
\hline Post-test & 69.96 & 11.43 \\
\hline
\end{tabular}

Based on the pre-test result data of critical thinking skills in the control class, the highest score is 25 , the lowest score is 3.571 and the pre-test average is 13.87 with the standard deviation of 6.91 .

Test result data of students' critical thinking skills after involving in the learning process, it was found the post-test result. The post-test in the control class was also conducted once as in the experiment class. Based on the post-test result, the highest score is 92.86 , the lowest score is 57.14 and the average score of the post-test is 69.96 with the standard deviation of 11.43 .

The learning outcome of students is in the form of pre-test and post-test scores processed which produced the pre-test and post-test average score. The average scores of pre-test in the control class and the experiment class are 13.87 and 16.19 , meanwhile, the average scores of the post-test in the control class and the experiment class are 69.96 and 82.38 .

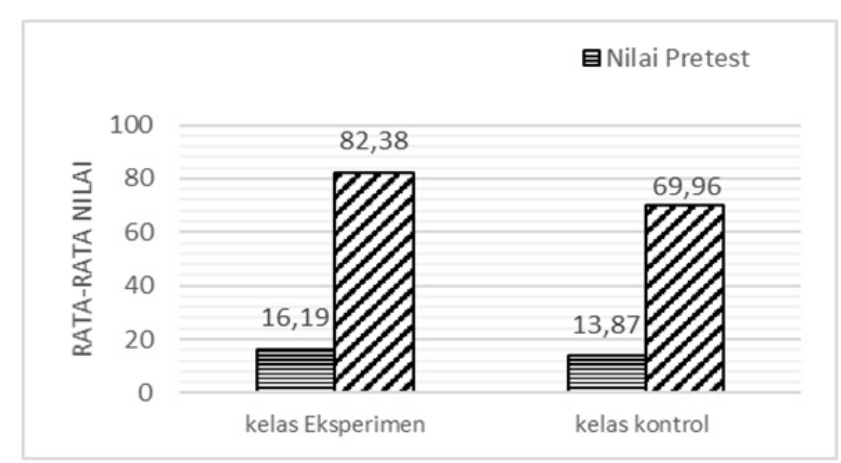

Figure 1. Chart of pre-test and post-test average score in experiment and control class

Based on Figure 1 above, the average scores of pre-test in experiment class and control class are almost the same. However, after given the learning with the different treatment, the average score of the post-test in the experiment class is higher than the average score of the post-test in control class.

Based on the average score of the post-test in experiment class which is 82.38 if it is found the criteria based on the category of students' critical thinking skill according [9] [13] [23] [24], it can be categorized as high. Meanwhile, in the control class, it is found that the post-test average score is 69.96 if it is categorized as medium. This category shows the percentage qualification of students' critical thinking skills.

Based on the data above, it is conducted t-test of two independent samples. The t-test result of two independent samples of students' critical thinking skills in experiment class and control class are provided in table 3 .

Table 3. T-test of Two Independent Samples

\begin{tabular}{|c|c|c|c|c|c|c|c|}
\hline Result & Class & $\mathrm{N}$ & Average & Variant & $\mathrm{T}_{\text {count }}$ & $\mathrm{T}_{\text {table }}(\mathrm{dk}=62)$ significant level $5 \%$ & Conclusion \\
\hline \multirow{2}{*}{ Pre-test } & Experiment & 30 & 16.19 & 71.02 & \multirow{2}{*}{1.27} & \multirow{2}{*}{2.00} & \multirow{2}{*}{$\begin{array}{l}\text { No difference on } \\
\text { the significance }\end{array}$} \\
\hline & Control & 34 & 13.87 & 47.75 & & & \\
\hline \multirow{2}{*}{ Post-test } & Experiment & 30 & 82.38 & 203.14 & \multirow{2}{*}{3.82} & \multirow{2}{*}{2.00} & \multirow{2}{*}{$\begin{array}{c}\text { Different } \\
\text { significance }\end{array}$} \\
\hline & Control & 34 & 69.69 & 130.73 & & & \\
\hline
\end{tabular}


The experiment class was provided with learning using the stimulation of video, discussion, and the explanation of the exercises by implementing Ethno science and doing the exercises provided in the handout. Meanwhile, the control class was provided with the learning by an explanation from the teachers and doing the exercises provided in the student's book. According to [4], it was stated that discussion is one of the effective ways in training and developing the critical thinking skill because, in the discussion, there is an idea exchange that students may consider, accept or reject their ideas or others so that it is suitable with the group's idea. Moreover, students can decrease the misunderstanding between themselves and the other students. Hence, due to the discussion, students may produce critical thinking skills.

In table 3, it can be seen that the use of the Ethno science-based Direct Instruction Learning Model influences the students' critical thinking skills. This research used the critical thinking skill proposed by [15]. [3] stated that there are three indicators in the aspects of delivering basic explanation, which are (1) focusing the questions, (2) analyzing the questions, (3) asking and answering questions about an explanation. The results of this research show that the use of local culture in the learning process should be conducted. It is in line with the statement of Rai (2001) in (Arfinawati, Sudarmin, \& Sumarni, 2016) which stated that education should bridge the gap of mainstream science with the local wisdom that is by using the aspects of local wisdom in the learning activity. The implementation of the Ethno science-based Direct Instruction Learning Model influenced the critical thinking skill because the learning model connects the classroom learning with the students' daily life and also motivate students to actively participate in the learning process. The implementation of Ethno science in the learning depends on the environment of students' living. Therefore, the teachers who will implement Ethno science in the classroom should understand the local wisdom around the living.

\section{Conclusions}

The implementation of the Ethno science-based Direct Instruction Learning Model influences the students' critical thinking skills because the learning model connects classroom learning and what the students' experience in their daily life for instance as dol music. Hence, it motivates students to actively participate in the learning process.

\section{REFERENCES}

[1] Afandi, M., Chamalah, E., \& Wardani, O. P. (2013). Model dan Metode Pembelajaran di Sekolah (1st ed.) [Models and Methods of Learning in Schools]. Semarang: UNISSULA Press.
[2] Andriani, S., Kesumawati, N., \& Kristiawan, M. (2018). The Influence of the Transformational Leadership and Work Motivation on Teachers Performance. International Journal of Scientific \& Technology Research, 7(7).

[3] Apriana, D., Kristiawan, M., \& Wardiah, D. (2019). Headmaster's Competency In Preparing Vocational School Students For Entrepreneurship. International Journal of Scientific \& Technology Research, 8(8).

[4] Arfianawati, S., Sudarmin, S., \& Sumarni, W. (2016). Model Pembelajaran Kimia Berbasis Etnosains Untuk Meningkatkan Kemampuan Berpikir Kritis Siswa [Ethnoscience-Based Chemistry Learning Model To Improve Students' Critical Thinking Ability]. Journal Pengajaran Matematikan Dan Ilmu Pengetahuan Alam, 21.https://doi.org/http://dx.doi.org/10.18 269/jpmipa.v21i1.669

[5] Damayanti, C., Rusilowati, A., \& Linuwih, S. (2017). Pengembangan Model Pembelajaran IPA Terintegrasi Etnosains untuk Meningkatkan Hasil Belajar dan Kemampuan Berpikir Kreatif [Development of Ethnographic Science Integrated Science Learning Model to Improve Learning Outcomes and Creative Thinking Ability]. Journal of Innovative Science Education, 6(1), 116-128.

[6] Dinissjah, M. J., Nirwana, N., \& Risdianto, E. (2019). Penggunaan Model Pembelajaran Direct Instruction Berbasis Etnosains Dalam Pembelajaran Fisika Untuk Meningkatkan Kemampuan Berpikir Kritis Siswa [The Use of Ethnographic Based Direct Instruction Learning Models in Physics Learning To Improve Students' Critical Thinking Ability]. Jurnal Kumparan Fisika, 2(2), 99-104. https://doi.org/10.333 69/jkf.2.2.99-104

[7] Fitria, H., Kristiawan, M., \& Rasyid, A. (2019). The Educational Character on Instruction. Opción, Año 35, Especial No.21 (2019): 964-979

[8] Fathurrochman, I., Budiman, D. A., Alamsyahril, \& Kristiawan, M. (2019). Revitalization Management of Islamic Boarding School Preventing The Radicalism. Restaurant Business, (10), 495-505.

[9] Irmayani, H., Wardiah, D., \& Kristiawan, M. (2018). The Strategy of SD Pusri In Improving Educational Quality. International Journal of Scientific \& Technology Research, $7(7)$.

[10] Khasanah, U., Kristiawan, M., \& Tobari. (2019). The Implementation of Principals' Academic Supervision In Improving Teachers' Professionalism in the State Primary Schools. International Journal of Scientific \& Technology Research, 8(8).

[11] Kistanto, N. H. (2017). Nurdien Harry Kistanto. Tentang Konsep Kebudayaan, 10(2), 1-11 [Cultural Concepts]. Retrieved from https://doi.org/10.14710/sabda.10.2.\%25p

[12] Kristiawan, M., Nizarani., \& Syamsidar. (2019). Role of School on Forming Character of Z-Generation Through Entrepreneurial Skills. International Journal of Scientific \& Technology Research, 8(10).

[13] Lian, B., Kristiawan, M., \& Fitriya, R. (2018). Giving Creativity Room to Students through the Friendly School's Program. International Journal of Scientific \& Technology Research, 7(7).

[14] Mulyasa, E. (2017). Pengembangan dan Implementasi 
Kurikulum 2013 [Development and Implementation of 2013 Curriculum]. Bandung: PT Remaja Rosdakarya.

[15] Novelti., Kristiawan, M., Erpidawati. (2019). Development of the Descriptive Writing Learning Model using the Audio Visual Media. International Journal of Recent Technology and Engineering, Volume-8 Issue-3, September 2019.

[16] Novitasari, L., Agustina, P. A., Sukesti, R., Nazri, M. F., \& Handhika, J. (2017). Makalah Pendamping ISSN: 2527-6670 Fisika , Etnosains , dan Kearifan Lokal dalam Pembelajaran Sains, 81-88 [Physics, Ethnoscience, and Local Wisdom in Science Learning].

[17] Rahayu, W. E., Semarang, U. N., \& Artikel, I. (2015). Pengembangan Modul IPA Terpadu Berbasis Etnosains Tema Energi Dalam Kehidupan Untuk Menanamkan Jiwa Konservasi Siswa [Development of Integrated Science Module Based on Ethnoscience Energy Themes in Life to Embed Students' Conservation Souls]. USEJ - Unnes Science Education Journal, 4(2). https://doi.org/10.15294/usej.v4i2.7 943

[18] Renata, R., Wardiah, D., \& Kristiawan, M. (2018). The Influence of Headmaster's Supervision and Achievement Motivation on Effective Teachers. International Journal of Scientific \& Technology Research, 7(4).

[19] Risdianto, E. (2019a). Analisis Pendidikan Indonesia di Era Revolusi Industri 4.0 [Analysis of Indonesian Education in the Era of the Industrial Revolution 4.0].

[20] Risdianto, E. (2019b). Development of Blended Learning Based on Web and Augmented Reality. 1st International Conference on Educational Sciences and Teacher Profession (ICETeP 2018, 295.

[21] Salwa., Kristiawan, M., \& Lian, B. (2019). The Effect of Academic Qualification, Work Experience and Work Motivation towards Primary School Principal Performance. International Journal of Scientific \& Technology Research, $8(8)$.

[22] Sarina., Kristiawan, M., \& Wardiah, D. (2019). Module Development the Utilization of Patchwork Fabric As Teaching Materials Crafts on the Subjects of Craft and Entrepreneurship For High School Students. International Journal of Scientific \& Technology Research, 8(5).

[23] Tobari., Kristiawan, M., \& Asvio, N. (2018). The Strategy of Headmaster on Upgrading Educational Quality In Asean Economic Community (AEC) Era. International Journal of Scientific \& Technology Research, 7(4).

[24] Wandasari, Y., Kristiawan, M., \& Arafat, Y. (2019). Policy Evaluation of School's Literacy Movement on Improving Discipline of State High School Students. International Journal of Scientific \& Technology Research, 8(4). 